\title{
EFFECT OF SPHERE CONFIGURATED PARTICLE DAMPER ON TRIBOLOGICAL PROPERTIES DURING BORING OF HARDENED STEEL
}

\author{
Lawrance Gunaraj, Sam Paul, Ebenezer Jacob Dhas \\ Department of Mechanical Engineering, Karunya Institute of Technology Sciences, Coimbatore - 641114, India. \\ Corresponding author: Lawrance Gunaraj, lawrancedevaraj@gmail.com
}

\begin{abstract}
Tool vibration is the most unfavourable element in the boring operation, as it contributes to poor surface finish, excessive tool wear, and progressive cutting force. Tool vibration mainly occurs due to the overhanging length of the boring tool and to overcome this factor an appropriate mechanism has to be established which helps to increase the production and quality of the product in manufacturing sector. An impact particle damper with variable material spheres, sphere diameter, and sphere location in a boring tool is fabricated in this work. A 27 run experiments were conducted to find the effect of impact particle damping on tribological properties during boring process. The results shows that impact particle damper increases the rigidity of the tool holder which enhances the tribological properties. The sphere in the boring tool will collide with one another thereby suppressing the tool vibration efficiently.
\end{abstract}

Key words: boring process; impact particle damper; tribological properties; filler size; ANOVA.

\section{INTRODUCTION}

The metal cutting industries is motivated towards high standard product and increased manufacturing. In manufacturing sector, the relative movement between metal cutting process and dynamics of machine tool leads to tool vibration (Lawrance et al., 2017). The overhanging length of the boring tool is a major reason for an enhanced tool vibration which results in high surface roughness and reduced tool life (Lawrance et al., 2019). In metal cutting industries, tool vibration is considered as a major challenge which can be controlled by providing a suitable damper. The impact dampers is an ease and simple elucidation to suppress tool vibration in a boring tool. Ramesh and Alwarsamy (2012) suggested that, an impact damper material with high density have added inertia mass which could suppress tool vibration. Sam Paul et al. (2015) suggested that the damping capacity of an impact damper made up of damping material is critical for tool vibration suppression during the turning phase. Panossian (1992) developed particle damping for structural application to suppress vibration. The small cavities are filled with particles which is positioned in a structure. The particles inside the structure collide with one another and cavity wall which leads to energy dissipation and damping. Sathishkumar et al. (2012) developed a particle damping technique which suppress chatter in a boring tool and reduce surface roughness. It was also found that $40 \%$ reduction in surface roughness when copper was used to fill boring bar hole. The particle damping is also applied on cantilever beam structure and found that $50 \%$ enhancement in damping (Friend and Kinra, 2000). Marhadi and Kinra (2005) stretched particle impact damping with different materials and found it's efficient. Diniz et al. (2019) developed a particle impact damper filled with particles inside the tool cavity. When vibration occurs these particles dissipate kinetic energy along with collision and friction with other particles. The high density material can be used as particles (Khatake and Nitnaware, 2013). The use of impact particle damping has been applied successfully in structural and machining operations.

The effect of an impact sphere particle damper on tribological properties during boring of AISI4340 steel was investigated in this study. The tribological properties consist of tool vibration, surface roughness, cutting force and tool wear. The boring tool's cavity is filled with balls, the diameter of which is lesser than the cavity diameter. As the boring instrument vibrates, the sphere inside dissipates energy by colliding with other spheres and the cavity wall, resulting in successful damping. A serious of cutting experiment were conducted on varying sphere diameter, sphere material and filling of spheres in boring cavity. To validate the cutting experiments data, an uncertainty analysis also done. The impact sphere particle damping used is a simple, inexpensive and effective technique to improve the tribological properties.

\section{MATERIAL AND METHODS}

In this study, a boring tool with a diameter of $25 \mathrm{~mm}$ and a length of $300 \mathrm{~mm}$ with the specification S25T PCLNR 12F3 was used. The work piece is made of 
AISI 4340 steel and has an outer diameter of $80 \mathrm{~mm}$, a diameter of $40 \mathrm{~mm}$, and a length of $100 \mathrm{~mm}$ (Lawrance et al., 2019). Figure 1 depicts the creation of a boring bar with an impact sphere damper. Spark machining was used to drill a carbon steel boring tool with an inner diameter of $10 \mathrm{~mm}$ and a length of 200 $\mathrm{mm}$. The spheres were placed in the boring cavity and secured with a screw that could be adjusted.

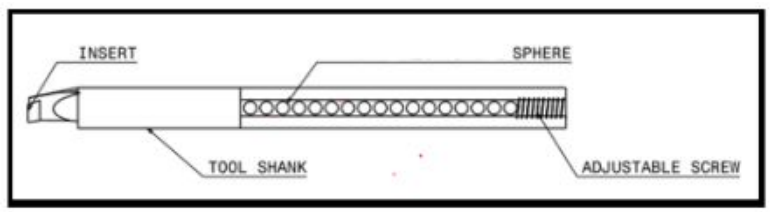

Fig. 1. Impact sphere damper in a boring bar

A piezoelectric vibrometer was used to measure tool vibration, a Kistler type 9257B dynamometer was used to measure cutting force, Mitutoyo - SJ 210 was used to measure average surface roughness, and Toolmakers' microscope was used to measure tool wear in cutting experiment on a Kirloskar turn master-35 lathe. A set of impact sphere particle damper parameters were arrived, namely the filling of spheres in boring cavity (tightly packed, loosely packed and partially packed), the sphere diameter $(4 \mathrm{~mm}, 6 \mathrm{~mm} \& 8 \mathrm{~mm})$ and the sphere material (stainless steel, chromium steel \& tungsten carbide) to enhance tribological properties. Table 1 shows three levels of impact sphere particle damper parameters, and Table 2 shows the experimental findings obtained during machining. A complete factorial experimental plan of type $2^{3}=27$ experiments was made with these parameters. The feed rate was kept constant at $0.06 \mathrm{~mm} / \mathrm{min}$, the cutting speed at $100 \mathrm{~m} / \mathrm{min}$, and the cut depth at $0.5 \mathrm{~mm}$. Cutting trials were carried out in a dry cutting environment for 2 minutes.

Table 1. Three level parameters of impact sphere particle damper

\begin{tabular}{|c|c|c|c|c|}
\hline \multirow{2}{*}{ No } & Parameter & \multicolumn{3}{|c|}{ Levels } \\
\cline { 3 - 5 } 1 & Sphere material & $\begin{array}{c}\text { stainless } \\
\text { steel }\end{array}$ & $\begin{array}{c}\text { chromium } \\
\text { steel }\end{array}$ & $\begin{array}{c}\text { tungsten } \\
\text { carbide }\end{array}$ \\
\hline 2 & $\begin{array}{c}\text { Sphere diameter } \\
(\mathrm{mm})\end{array}$ & 4 & 6 & 8 \\
\hline 3 & Spheres filling & $\begin{array}{c}\text { tightly } \\
\text { packed }\end{array}$ & $\begin{array}{c}\text { loosly } \\
\text { packed }\end{array}$ & $\begin{array}{c}\text { partially } \\
\text { packed }\end{array}$ \\
\hline
\end{tabular}

\section{ANALYSIS OF VARIANCE (ANOVA)}

ANOVA is used to find the effect of input variables on the machinability of the boring process. ANOVA is also engaged to identify the significant cutting parameters affecting machinability of the material (Yang and Tarng, 1998). The equation given below is used to estimate the total sum of squared deviations which is used to rank the cutting parameters and it was done was using MINITAB 16 software. Here, $n$ is the number of experiments, $\eta_{\mathrm{m}}$ is the total mean signal to noise ratio and $\eta_{\mathrm{i}}$ is the mean signal to noise ratio for the $\mathrm{i}^{\text {th }}$ experiment (Lawrance et al., 2019).

$$
\mathrm{SS}_{\mathrm{T}}=\sum_{i=1}^{n}\left(\eta_{\mathrm{i}}-\eta_{\mathrm{m}}\right)^{2}
$$

\section{RESULTS AND DISCUSSION}

The contour plot shown in Figure 2(a), reveals that tool vibration is suppressed $(0.5-1 \mathrm{~mm})$ at the interaction of level 3 of sphere diameter $(8 \mathrm{~mm})$ and sphere material (tungsten carbide). But tool vibration is high $(3-3.5 \mathrm{~mm})$ at most of the level 1 region of sphere diameter $(4 \mathrm{~mm})$ and sphere material (stainless steel). Similarly contour plot shown in Figure 2(b), reveals that tool vibration is suppressed $(0.5-1 \mathrm{~mm})$ at the interaction of level 3 of sphere filling (partially packed) and sphere material (tungsten carbide). But tool vibration is high $(3-3.5 \mathrm{~mm})$ at most of the level 1 region of sphere filling (tightly packed) and sphere material (stainless steel). The contour plot shown in Figure 2(c), reveals that tool vibration is middling (1 $-1.5 \mathrm{~mm})$ at level 3 region of sphere diameter $(8 \mathrm{~mm})$ and sphere filling (partially packed). But tool vibration is high $(2.5-3 \mathrm{~mm})$ at level 1 region of sphere filling (tightly packed) and sphere diameter $(4 \mathrm{~mm})$. Figures 2(a), 2(b), and 2(c) demonstrate the results of the variable sphere material, sphere diameter, and sphere fillings test for amplitude of tool vibration. It was found that when the tool holder was filled with impact sphere particle damper with tungsten carbide sphere material, sphere diameter of $8 \mathrm{~mm}$, and sphere fillings of partially packed, there was a significant reduction in tool vibration.

The contour plot shown in Figure 3(a), reveals that surface roughness is reduced (less than $1 \mu \mathrm{m}$ ) at the interaction of level 3 of sphere filling (partially packed) and sphere material (tungsten carbide). But surface roughness is high (more than $2 \mu \mathrm{m}$ ) at level 1 \& 2 region of sphere filling (tightly \& loosely packed) and sphere material (stainless steel \& chromium). Similarly contour plot shown in Figure 3(b), reveals that surface roughness is reduced (less than $1 \mu \mathrm{m})$ at the interaction of level 3 of sphere diameter $(8 \mathrm{~mm})$ and sphere material (tungsten carbide). But surface roughness is high (more than $2 \mu \mathrm{m})$ at level $1 \& 2$ region of sphere diameter $(4 \&$ $6 \mathrm{~mm}$ ) and sphere material (stainless steel \& chromium). The contour plot shown in Figure 3(c), reveals that surface roughness is mediocre $(1-2 \mu \mathrm{m})$ at level 3 region of sphere diameter $(8 \mathrm{~mm})$ and sphere filling (partially packed). But surface roughness is very high (above $3 \mu \mathrm{m}$ ) at level 1 region 
of sphere filling (tightly packed) and sphere diameter (4). The variable sphere material, sphere diameter, and sphere fillings test for surface roughness shown in Figures 3(a), 3(b), and 3(c) revealed that when the tool holder was equipped with an impact sphere particle damper made of tungsten carbide and filled partially, the surface roughness was significantly reduced.

Table 2. Experimental design and results

\begin{tabular}{|c|c|c|c|c|c|c|c|}
\hline \multirow[b]{2}{*}{$\begin{array}{c}\text { Standard } \\
\text { Order }\end{array}$} & \multicolumn{3}{|c|}{ Factor } & \multirow{2}{*}{$\begin{array}{l}\text { Vibration } \\
\text { amplitude of } \\
\text { tool }(\mathrm{mm})\end{array}$} & \multirow{2}{*}{$\begin{array}{l}\text { Cutting } \\
\text { Force } \\
\text { (N) }\end{array}$} & \multirow{2}{*}{$\begin{array}{c}\text { Surface } \\
\text { Roughness, Ra } \\
(\mu \mathrm{m})\end{array}$} & \multirow{2}{*}{$\begin{array}{l}\text { Tool } \\
\text { Wear } \\
(\mathrm{mm})\end{array}$} \\
\hline & $\begin{array}{c}\text { Sphere } \\
\text { diameter }\end{array}$ & Sphere filling & $\begin{array}{c}\text { Sphere } \\
\text { material }\end{array}$ & & & & \\
\hline 1 & 4 & $\begin{array}{l}\text { tightly } \\
\text { packed }\end{array}$ & $\begin{array}{c}\text { stainless } \\
\text { steel }\end{array}$ & 3.77 & 1243 & 4.48 & 0.233 \\
\hline 2 & 4 & $\begin{array}{l}\text { tightly } \\
\text { packed }\end{array}$ & $\begin{array}{c}\text { chromium } \\
\text { steel }\end{array}$ & 3.28 & 1010 & 4.43 & 0.189 \\
\hline 3 & 4 & $\begin{array}{l}\text { tightly } \\
\text { packed }\end{array}$ & $\begin{array}{l}\text { tungsten } \\
\text { carbide }\end{array}$ & 2.77 & 585 & 3.84 & 0.181 \\
\hline 4 & 4 & loosly packed & $\begin{array}{c}\text { stainless } \\
\text { steel }\end{array}$ & 3.27 & 1069 & 4.82 & 0.213 \\
\hline 5 & 4 & loosly packed & $\begin{array}{c}\text { chromium } \\
\text { steel }\end{array}$ & 2.77 & 368 & 4.15 & 0.199 \\
\hline 6 & 4 & loosly packed & $\begin{array}{l}\text { tungsten } \\
\text { carbide }\end{array}$ & 2.27 & 659 & 3.27 & 0.151 \\
\hline 7 & 4 & $\begin{array}{c}\text { partially } \\
\text { packed }\end{array}$ & $\begin{array}{c}\text { stainless } \\
\text { steel }\end{array}$ & 2.78 & 858 & 3.38 & 0.131 \\
\hline 8 & 4 & $\begin{array}{c}\text { partially } \\
\text { packed }\end{array}$ & $\begin{array}{c}\text { chromium } \\
\text { steel }\end{array}$ & 2.27 & 980 & 3.89 & 0.137 \\
\hline 9 & 4 & $\begin{array}{c}\text { partially } \\
\text { packed }\end{array}$ & $\begin{array}{l}\text { tungsten } \\
\text { carbide }\end{array}$ & 1.77 & 815 & 2.55 & 0.094 \\
\hline 10 & 6 & $\begin{array}{l}\text { tightly } \\
\text { packed }\end{array}$ & $\begin{array}{c}\text { stainless } \\
\text { steel }\end{array}$ & 2.27 & 1208 & 4.66 & 0.191 \\
\hline 11 & 6 & $\begin{array}{l}\text { tightly } \\
\text { packed }\end{array}$ & $\begin{array}{c}\text { chromium } \\
\text { steel }\end{array}$ & 1.77 & 995 & 4.81 & 0.159 \\
\hline 12 & 6 & $\begin{array}{l}\text { tightly } \\
\text { packed }\end{array}$ & $\begin{array}{l}\text { tungsten } \\
\text { carbide }\end{array}$ & 2.61 & 939 & 3.45 & 0.16 \\
\hline 13 & 6 & loosly packed & $\begin{array}{c}\text { stainless } \\
\text { steel }\end{array}$ & 2.24 & 749 & 4.29 & 0.194 \\
\hline 14 & 6 & loosly packed & $\begin{array}{c}\text { chromium } \\
\text { steel }\end{array}$ & 2.78 & 993 & 4.12 & 0.157 \\
\hline 15 & 6 & loosly packed & $\begin{array}{l}\text { tungsten } \\
\text { carbide }\end{array}$ & 2.25 & 743 & 3.50 & 0.102 \\
\hline 16 & 6 & $\begin{array}{c}\text { partially } \\
\text { packed }\end{array}$ & $\begin{array}{c}\text { stainless } \\
\text { steel }\end{array}$ & 3.03 & 458 & 3.45 & 0.151 \\
\hline 17 & 6 & $\begin{array}{c}\text { partially } \\
\text { packed }\end{array}$ & $\begin{array}{c}\text { chromium } \\
\text { steel }\end{array}$ & 2.30 & 457 & 2.71 & 0.089 \\
\hline 18 & 6 & $\begin{array}{c}\text { partially } \\
\text { packed }\end{array}$ & $\begin{array}{l}\text { tungsten } \\
\text { carbide }\end{array}$ & 1.72 & 368 & 0.17 & 0.023 \\
\hline 19 & 8 & $\begin{array}{l}\text { tightly } \\
\text { packed }\end{array}$ & $\begin{array}{c}\text { stainless } \\
\text { steel }\end{array}$ & 2.41 & 1112 & 3.17 & 0.142 \\
\hline 20 & 8 & $\begin{array}{l}\text { tightly } \\
\text { packed }\end{array}$ & $\begin{array}{c}\text { chromium } \\
\text { steel }\end{array}$ & 1.93 & 399 & 2.69 & 0.139 \\
\hline 21 & 8 & $\begin{array}{l}\text { tightly } \\
\text { packed }\end{array}$ & $\begin{array}{l}\text { tungsten } \\
\text { carbide }\end{array}$ & 1.43 & 638 & 1.56 & 0.092 \\
\hline 22 & 8 & loosly packed & $\begin{array}{c}\text { stainless } \\
\text { steel }\end{array}$ & 1.89 & 954 & 3.37 & 0.103 \\
\hline
\end{tabular}




\begin{tabular}{|c|c|c|c|c|c|c|c|}
\hline 23 & 8 & loosly packed & $\begin{array}{c}\text { chromium } \\
\text { steel }\end{array}$ & 1.40 & 816 & 2.52 & 0.079 \\
\hline 24 & 8 & loosly packed & $\begin{array}{c}\text { tungsten } \\
\text { carbide }\end{array}$ & 0.77 & 494 & 1.10 & 0.062 \\
\hline 25 & 8 & $\begin{array}{c}\text { partially } \\
\text { packed }\end{array}$ & $\begin{array}{c}\text { stainless } \\
\text { steel }\end{array}$ & 1.45 & 458 & 1.52 & 0.023 \\
\hline 26 & 8 & $\begin{array}{c}\text { partially } \\
\text { packed }\end{array}$ & $\begin{array}{c}\text { chromium } \\
\text { steel }\end{array}$ & 0.73 & 554 & 0.89 & 0.029 \\
\hline 27 & 8 & $\begin{array}{c}\text { partially } \\
\text { packed }\end{array}$ & $\begin{array}{c}\text { tungsten } \\
\text { carbide }\end{array}$ & 0.19 & 168 & 0.09 & 0.013 \\
\hline
\end{tabular}

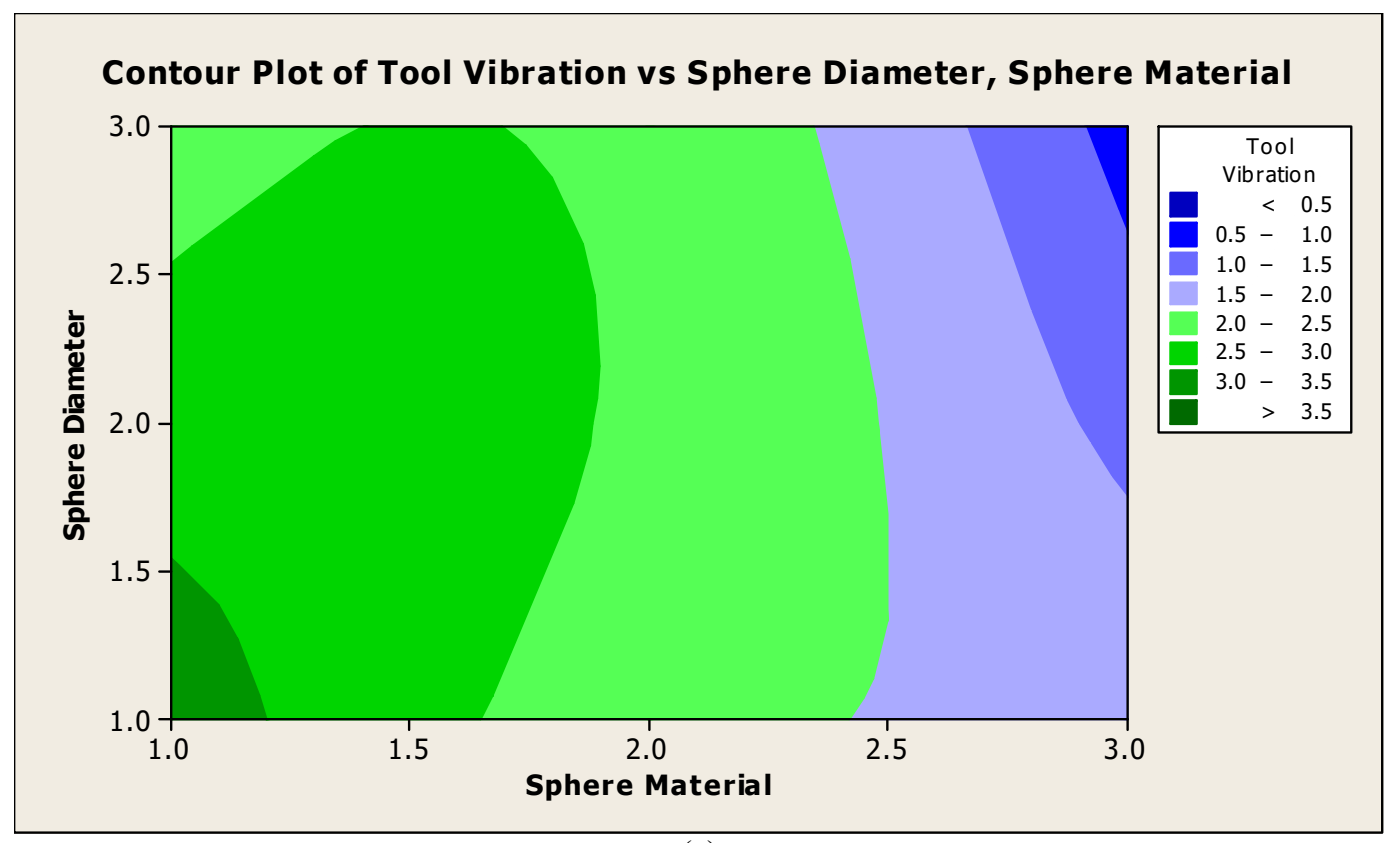

(a)

\section{Contour Plot of Tool Vibration vs Sphere Filling, Sphere Material}

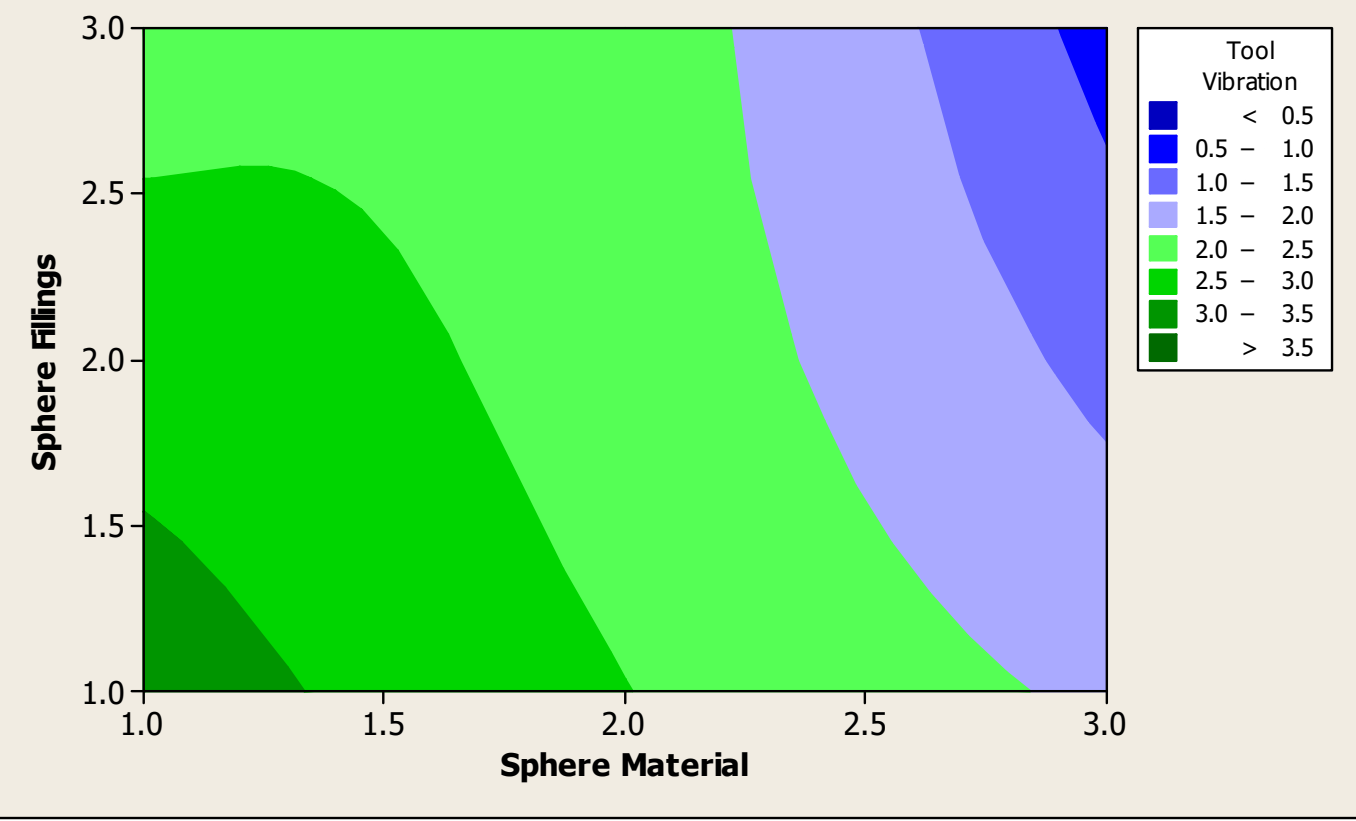

(b) 


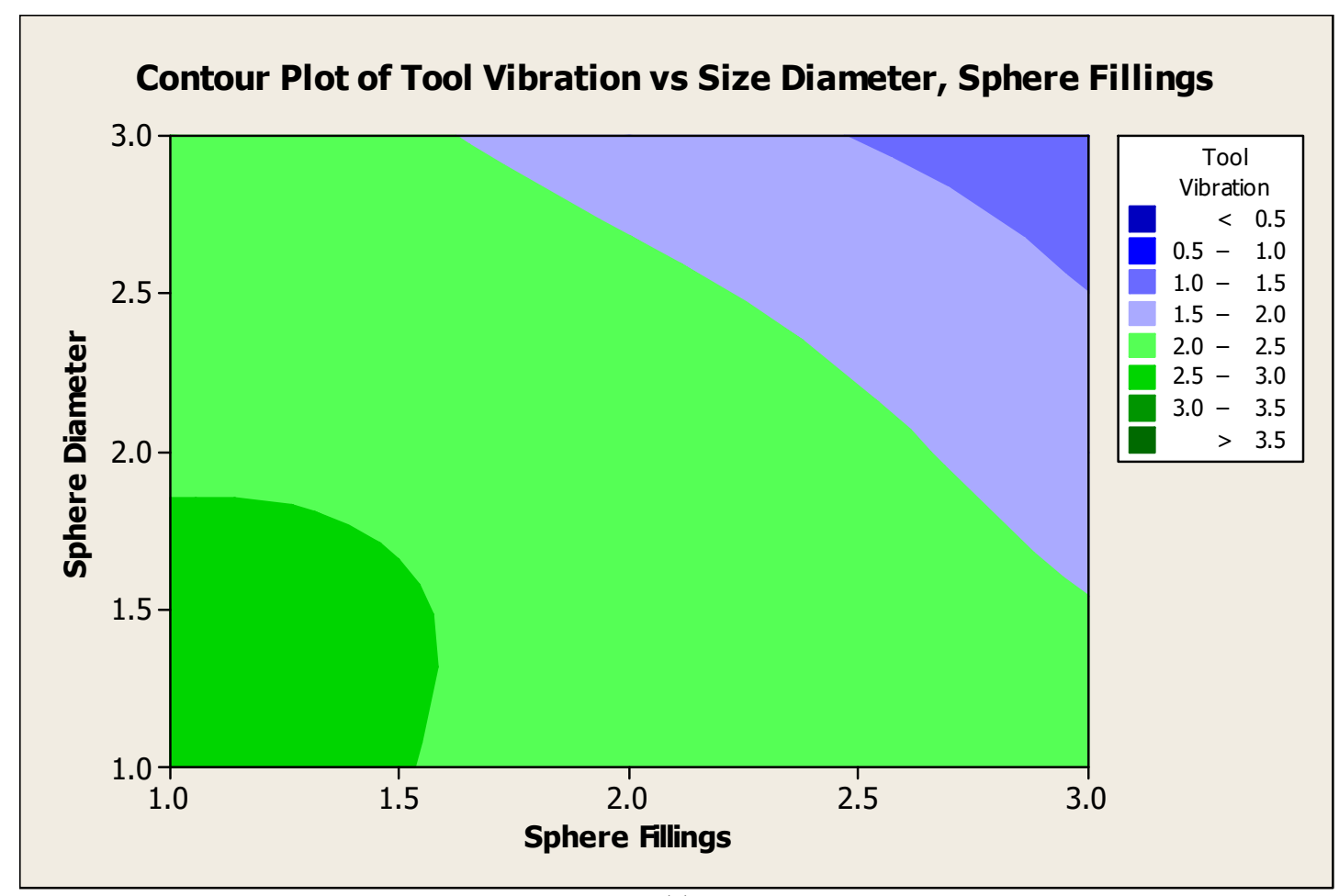

(c)

Fig. 2. Contour plot of tool vibration

Contour Plot of Surface Roughness vs Sphere Fillings, Sphere Material
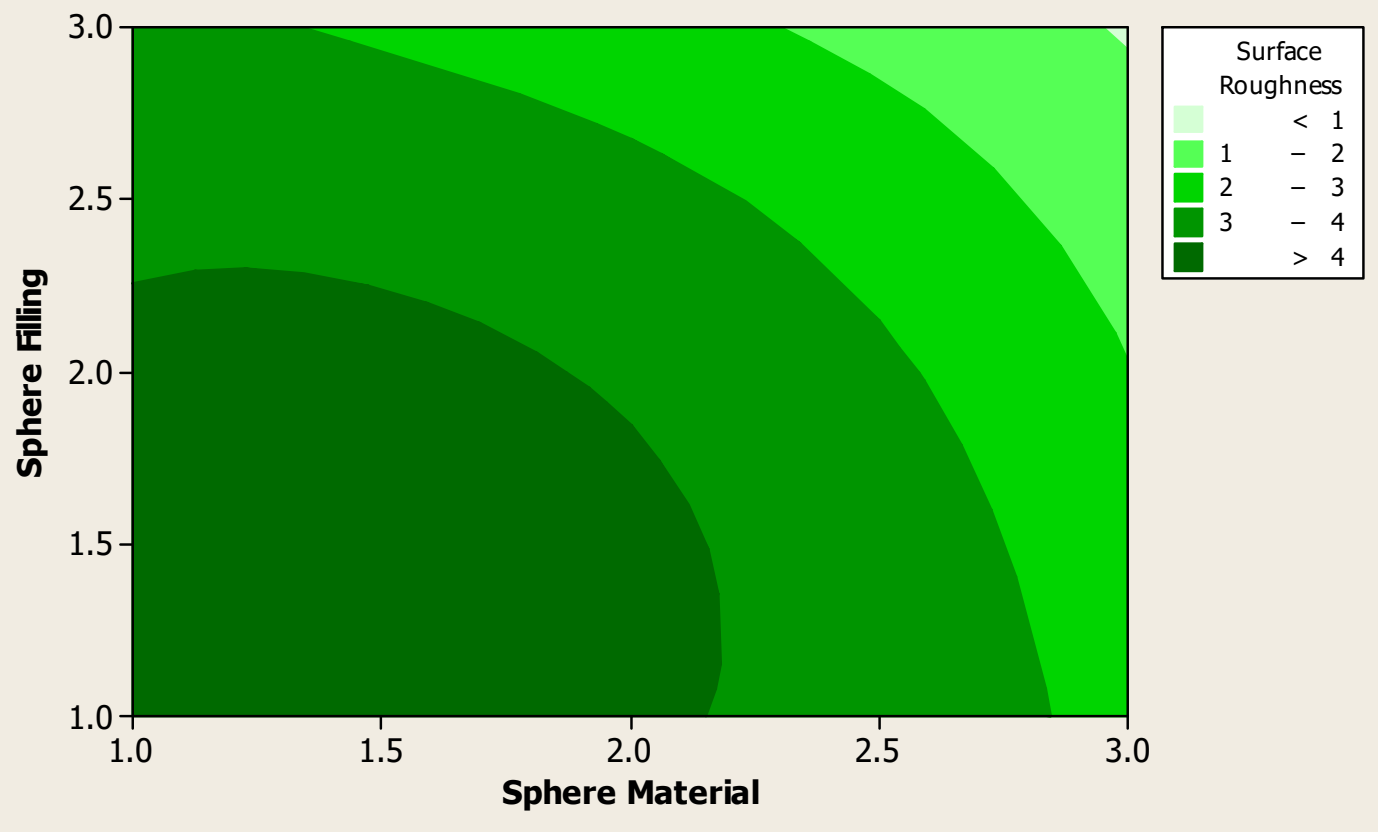

(a) 
Contour Plot of Surface Roughness vs Sphere Diameter, Sphere Material
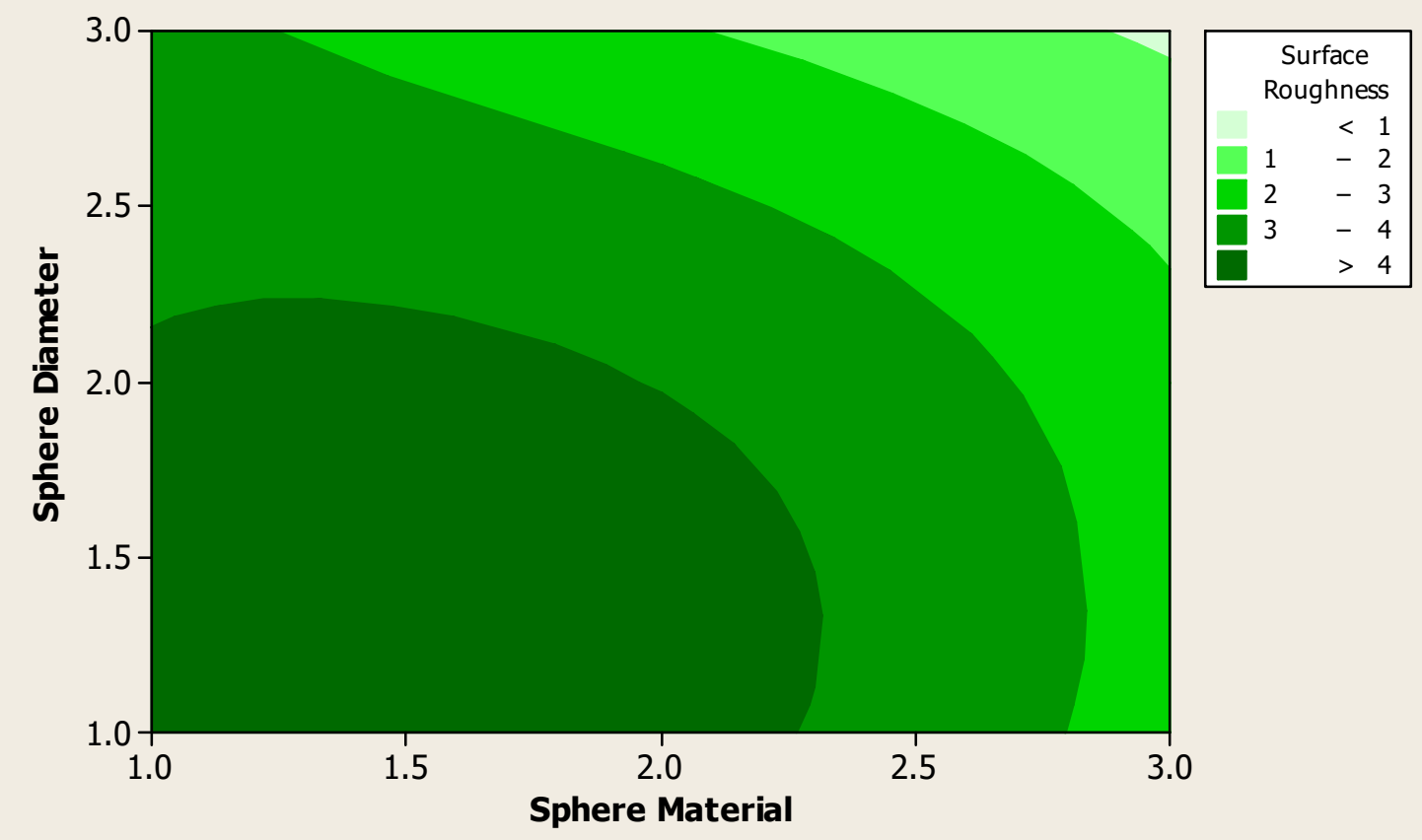

(b)

Contour Plot of Surface Roughness vs Sphere Diameter, Sphere Fillings

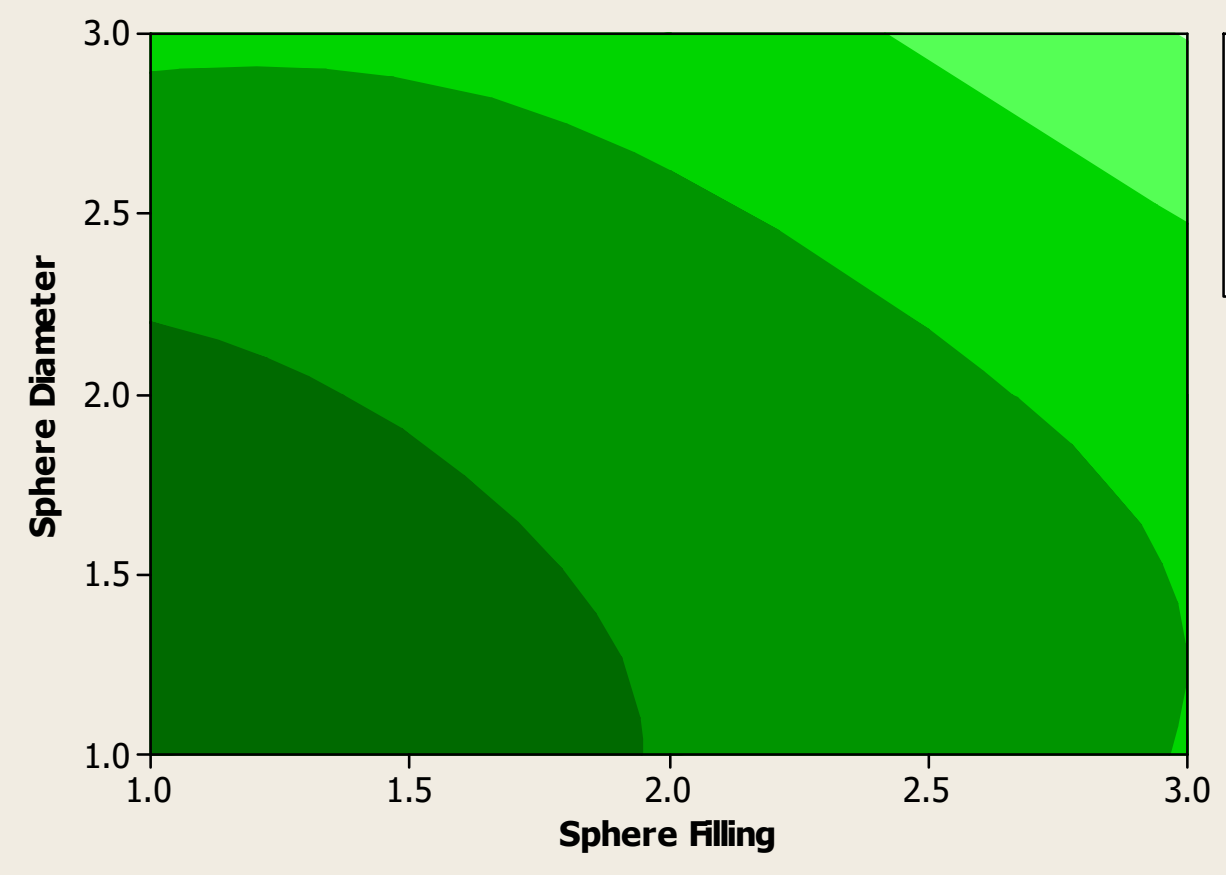

Fig. 3. Contour plot of surface roughness 


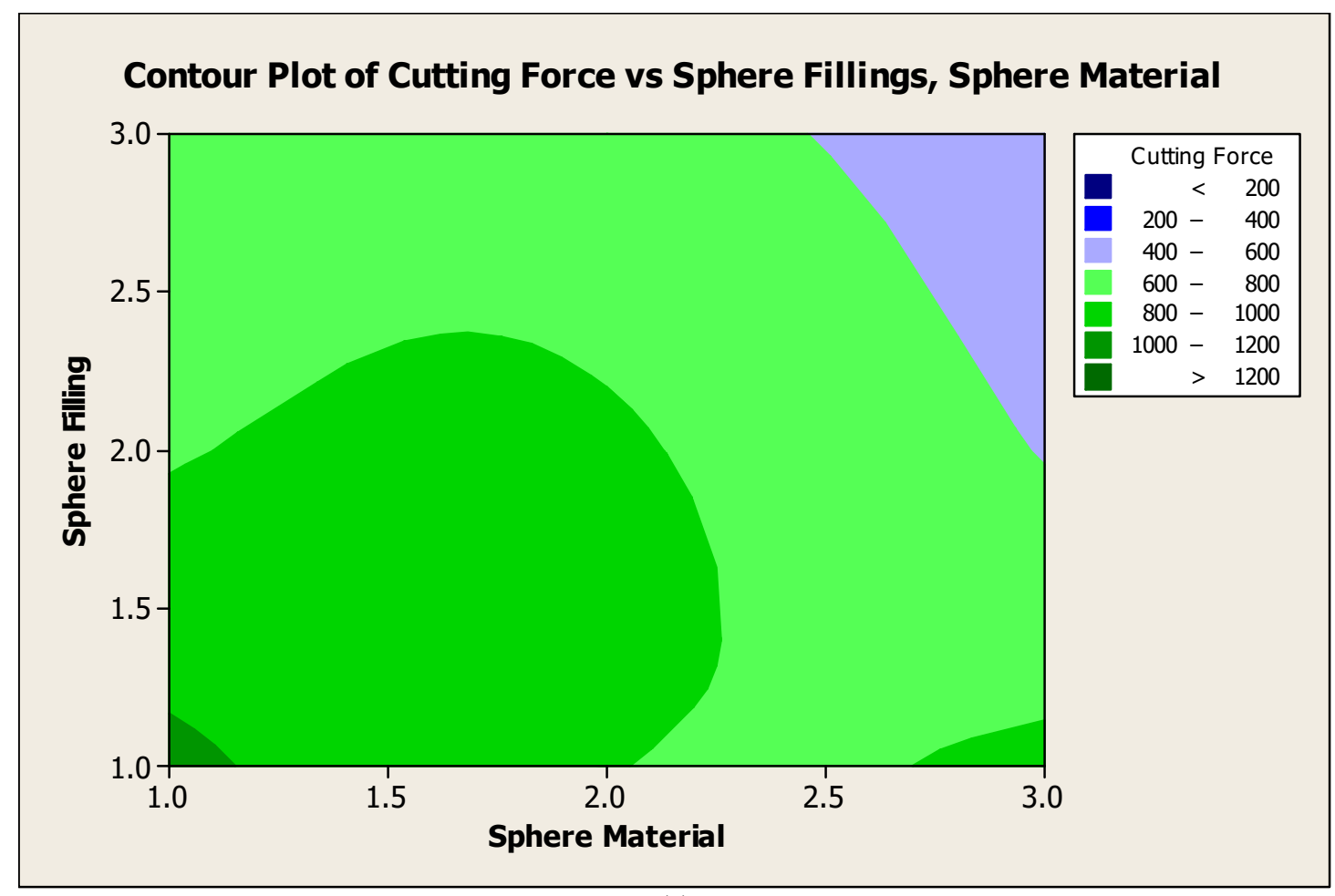

(a)

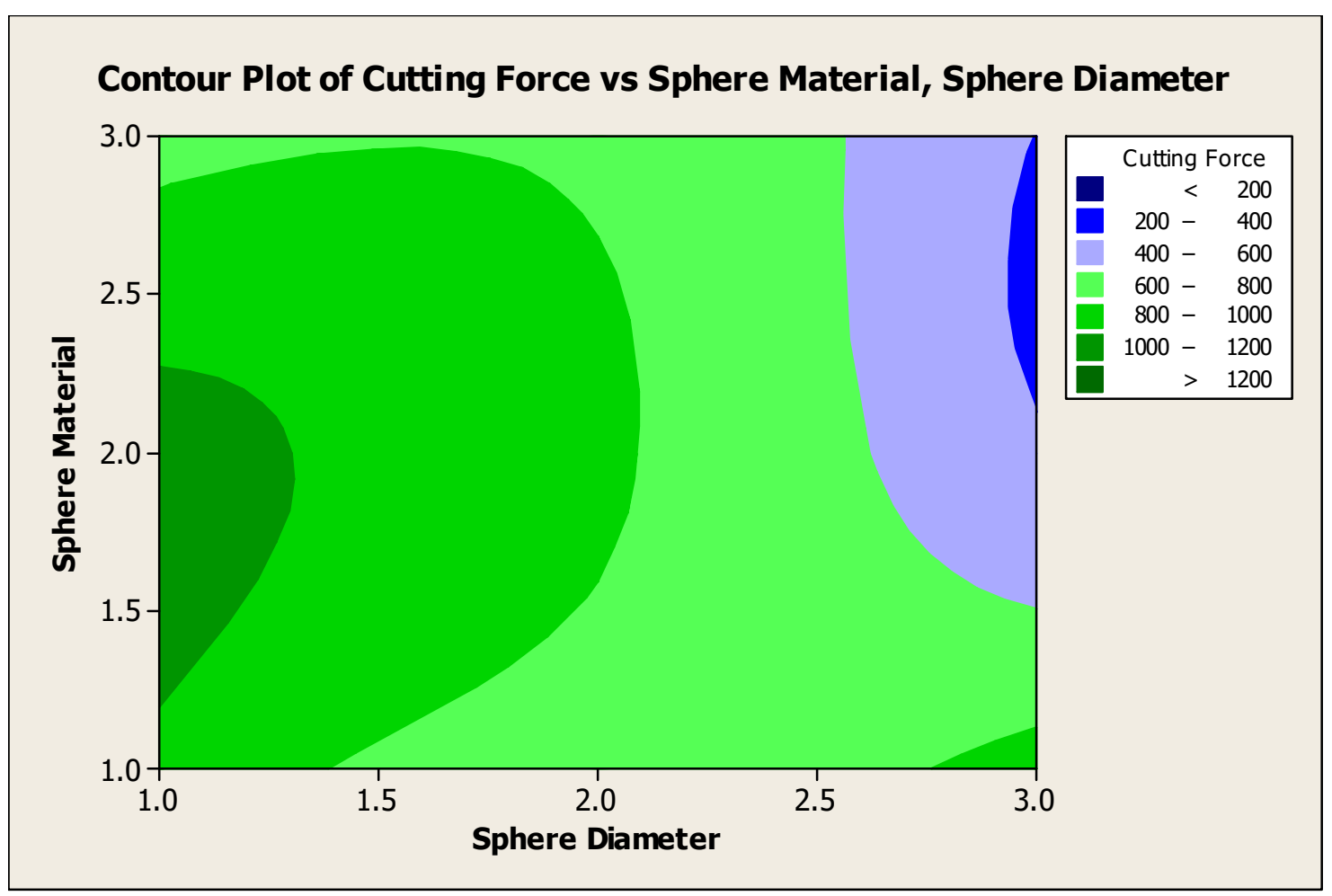

(b) 


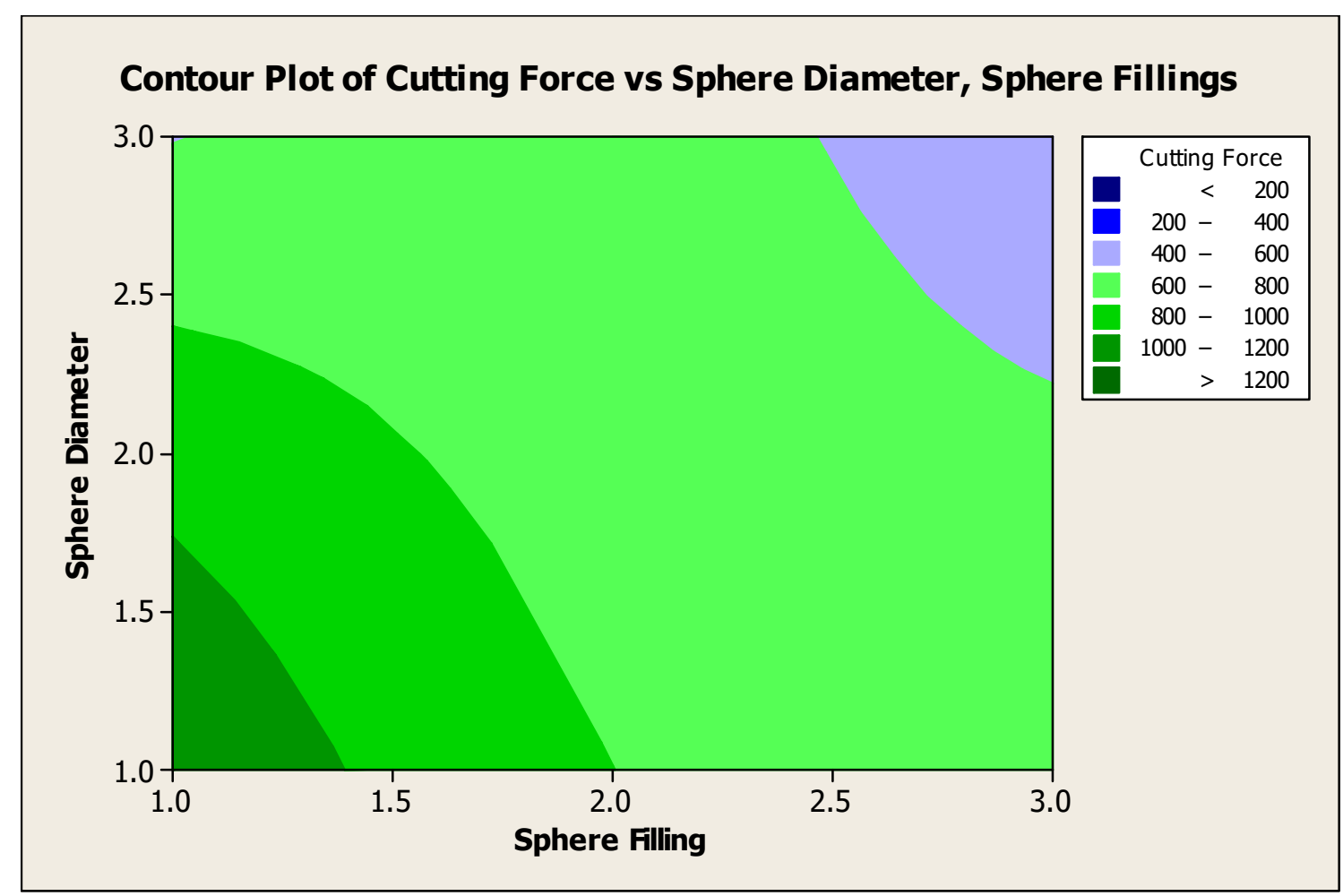

(c)

Fig. 4. Contour plot of cutting force

\section{Contour Plot of Tool Wear vs Sphere Filling, Sphere Material}

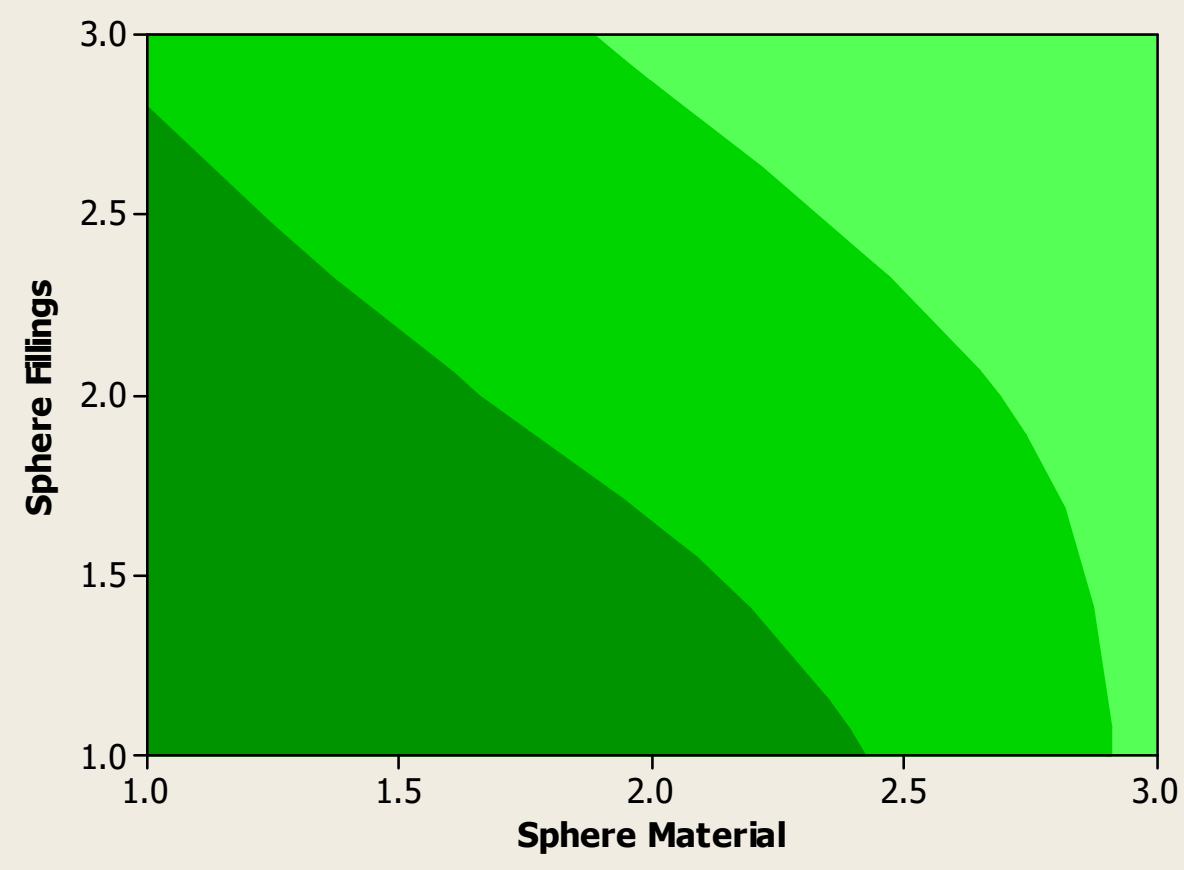

Tool Wear 


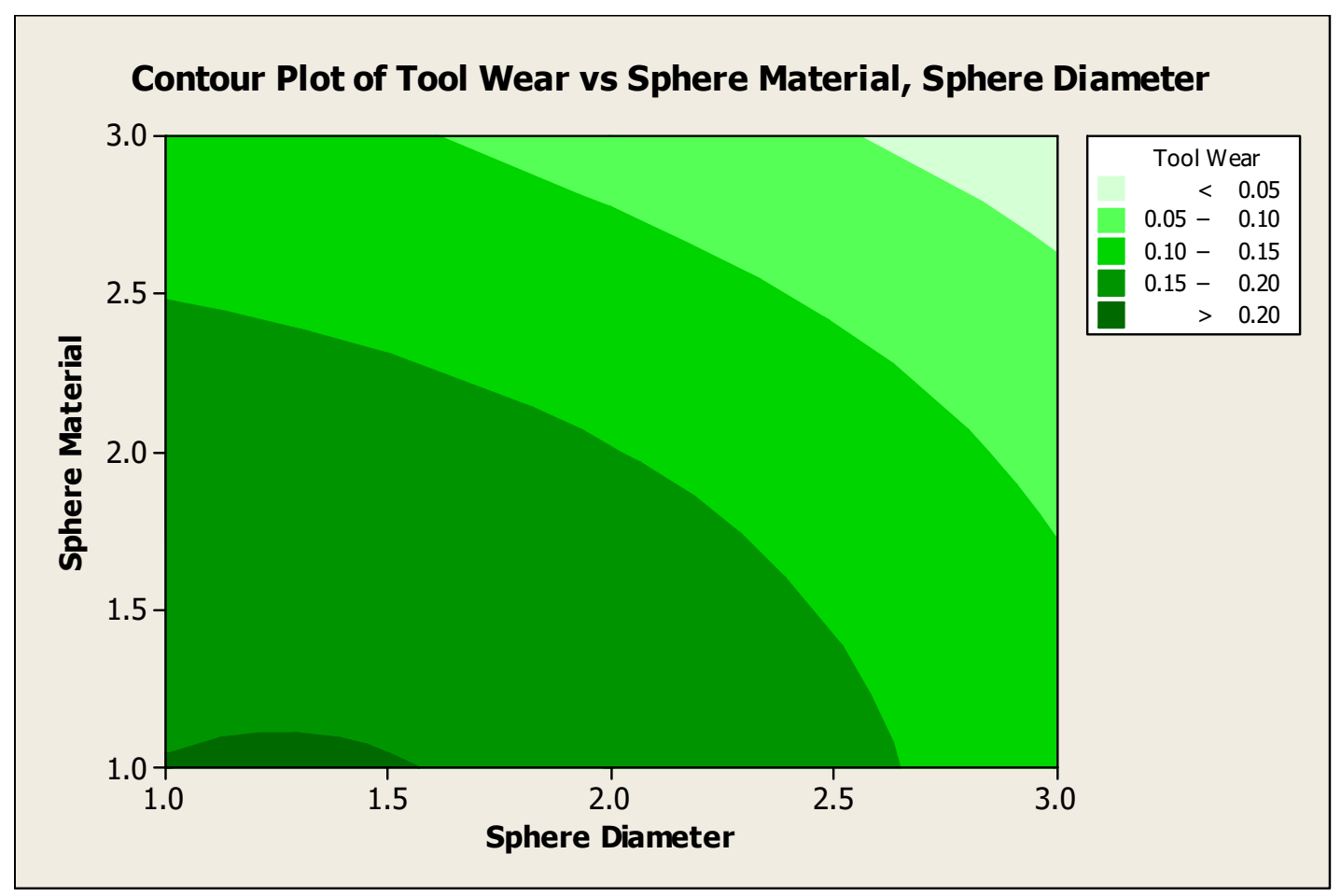

(b)

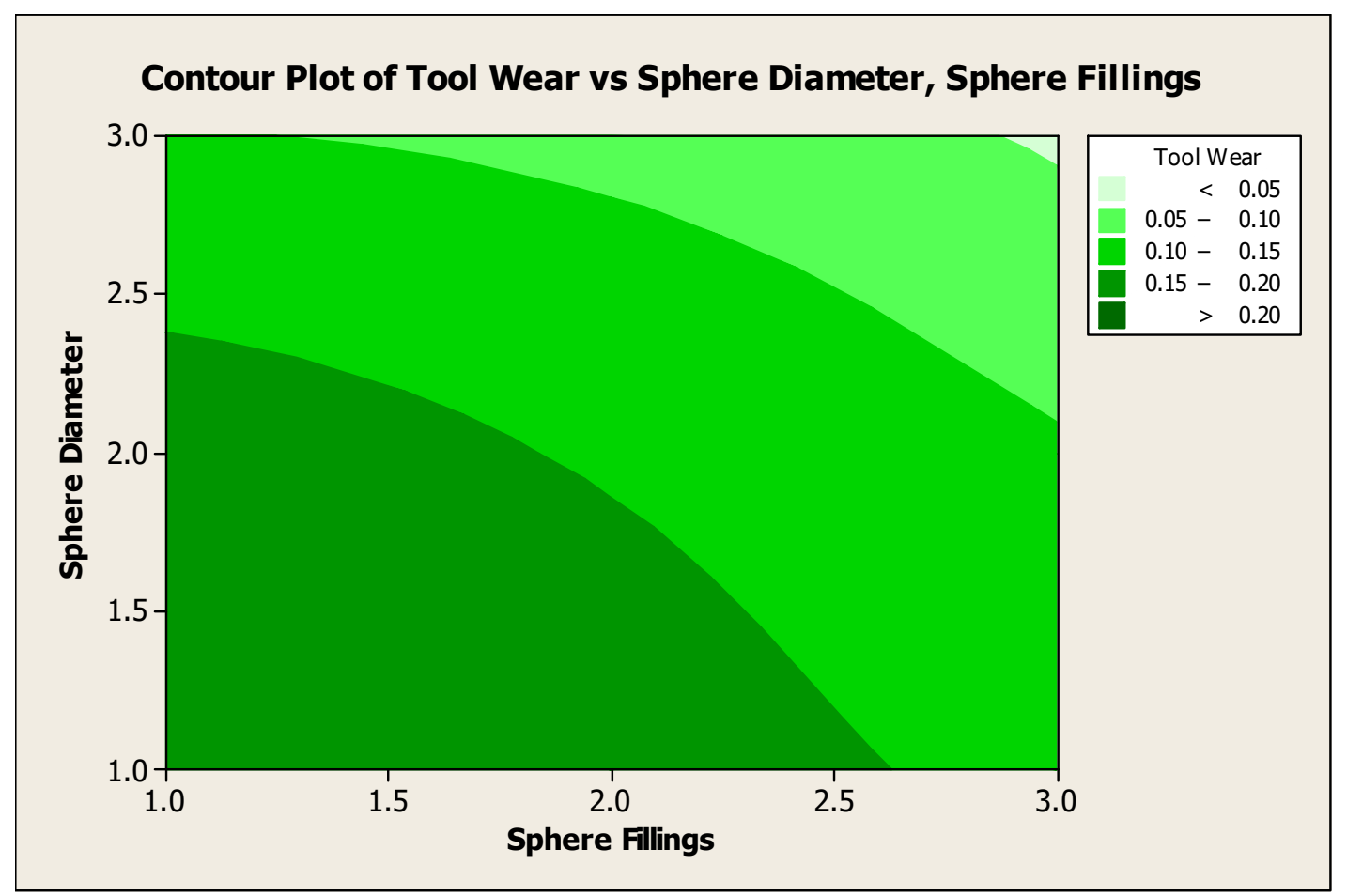

(c)

Fig. 5. Contour plot of tool wear

Table 3. ANOVA for tool vibration

\begin{tabular}{|c|c|c|c|c|c|c|c|}
\hline Source & DF & Seq SS & Adj SS & Adj MS & F & P & Contribution\% \\
\hline Sphere material & 2 & 23.5490 & 23.5490 & 11.7745 & 70.94 & 0.000 & 47.85 \\
\hline Sphere diameter & 2 & 14.2692 & 14.2692 & 7.1346 & 42.99 & 0.000 & 28.99 \\
\hline Filling of spheres & 2 & 8.0751 & 8.0751 & 4.0376 & 24.33 & 0.000 & 16.40 \\
\hline Error & 20 & 3.3194 & 3.3194 & 0.1660 & & & 6.74 \\
\hline Total & 26 & 49.2127 & & & & & \\
\hline
\end{tabular}


Table 4. ANOVA for cutting force

\begin{tabular}{|c|c|c|c|c|c|c|c|}
\hline Source & DF & Seq SS & Adj SS & Adj MS & F & P & Contribution\% \\
\hline Sphere material & 2 & 10365289 & 10365289 & 5182644 & 41.11 & 0.000 & 39.83 \\
\hline Sphere diameter & 2 & 8685078 & 8685078 & 4342539 & 34.44 & 0.000 & 33.37 \\
\hline Filling of spheres & 2 & 4447179 & 4447179 & 2223589 & 17.64 & 0.000 & 17.09 \\
\hline Error & 20 & 2521557 & 2521557 & 126078 & & & 9.69 \\
\hline Total & 26 & 26019103 & & & & & \\
\hline
\end{tabular}

Table 5. ANOVA for surface roughness

\begin{tabular}{|c|c|c|c|c|c|c|c|}
\hline Source & DF & Seq SS & Adj SS & Adj MS & F & P & Contribution\% \\
\hline Sphere material & 2 & 19.8903 & 19.8903 & 9.9452 & 42.26 & 0.000 & 40.10 \\
\hline Sphere diameter & 2 & 13.5926 & 13.5926 & 6.7963 & 28.88 & 0.000 & 27.40 \\
\hline Filling of spheres & 2 & 11.4036 & 11.4036 & 5.7018 & 24.23 & 0.000 & 22.99 \\
\hline Error & 20 & 4.7065 & 4.7065 & 0.2353 & & & 9.49 \\
\hline Total & 26 & 49.5929 & & & & & \\
\hline
\end{tabular}

Table 6. ANOVA for tool wear

\begin{tabular}{|c|c|c|c|c|c|c|c|}
\hline Source & DF & Seq SS & Adj SS & Adj MS & F & P & Contribution\% \\
\hline Sphere material & 2 & 0.040847 & 0.040847 & 0.020423 & 57.80 & 0.000 & 41.04 \\
\hline Sphere diameter & 2 & 0.037392 & 0.037392 & 0.018696 & 52.91 & 0.000 & 37.56 \\
\hline Filling of spheres & 2 & 0.014223 & 0.014223 & 0.007112 & 20.13 & 0.000 & 14.29 \\
\hline Error & 20 & 0.007067 & 0.007067 & 0.000353 & & & 7.10 \\
\hline Total & 26 & 0.099529 & & & & & \\
\hline
\end{tabular}

The contour plot shown in Figure 4(a), reveals that cutting force has significant reduction $(400-600 \mathrm{~N})$ at the level 3 region of sphere filling (partially packed) and sphere material (tungsten carbide). But cutting force is substantial high $(800-1000 \mathrm{~N})$ at level 1 region of sphere filling (tightly packed) and sphere material (4mm). Similarly contour plot shown in Figure 4(b), reveals that cutting force is reduced $(200-400 \mathrm{~N})$ at the interaction of level 3 of sphere diameter $(8 \mathrm{~mm})$ and sphere material (tungsten carbide). But cutting force is substantial high (800 $1000 \mathrm{~N})$ at level 1 region of sphere diameter $(4 \mathrm{~mm})$ and sphere material (stainless steel). The contour plot shown in Figure 4(c), reveals that cutting force has significant reduction $(400-600 \mathrm{~N})$ at level 3 region of sphere diameter $(8 \mathrm{~mm})$ and sphere filling (partially packed). But cutting force is very high (1000 $1200 \mathrm{~N}$ ) at level 1 region of sphere filling (tightly packed) and sphere diameter (4mm). Figures 4(a), 4(b), and 4(c) show the results of the variable sphere material, sphere diameter, and sphere fillings test for cutting force. It was discovered that when the tool holder was equipped with an impact sphere particle damper made of tungsten carbide and filled partially, the cutting force was significantly reduced.

The contour plot shown in Figure 5(a), reveals that tool wear has significant reduction $(0.05-0.1 \mathrm{~mm})$ at the level 3 region of sphere filling (partially packed) and sphere material (tungsten carbide). But tool wear is substantial high $(0.15-0.2 \mathrm{~mm})$ at level 1 region of sphere filling (tightly packed) and sphere material (4mm). Similarly contour plot shown in Figure 5(b), reveals that tool wear is reduced (less than $0.05 \mathrm{~mm}$ ) at the interaction of level 3 of sphere diameter (8mm) and sphere material (tungsten carbide). But tool wear is substantial high (more than $0.2 \mathrm{~mm}$ ) at the interaction of level 1 region of sphere diameter $(4 \mathrm{~mm})$ and sphere material (stainless steel). The contour plot shown in Figure 5(c), reveals that tool wear has significant reduction (less than $0.05 \mathrm{~mm}$ ) at the interaction of level 3 region of sphere diameter (8mm) and sphere filling (partially packed). But tool wear is high $(0.15-0.2 \mathrm{~mm})$ at most of the level $1 \&$ region of sphere filling (tightly \& loosely packed) and sphere diameter (4\& $6 \mathrm{~mm}$ ). In the variable sphere material, sphere diameter, and sphere fillings test for tool wear seen in Figures 5(a), 5(b), and 5(c), it was discovered that when the tool holder was equipped with an impact sphere particle damper made of tungsten carbide and filled partially, there was a significant reduction in tool wear.

Table 3 shows the percentage contributions of sphere material, sphere diameter, and sphere filling in boring cavity parameters on tool vibration, which were found to be $47.85 \%, 28.99 \%$, and $16.40 \%$, respectively. From ANOVA analysis, shown in Table 3 , it was observed that sphere material contributes significantly in reducing tool vibration when compared to sphere diameter and filling of spheres. Table 4 shows that the sphere material, sphere diameter, and filling of spheres parameters contributed $39.83 \%, 33.37 \%$, and $17.09 \%$, respectively, to cutting force. Table 5 shows that the sphere material, sphere diameter, and filling of spheres parameters each contribute $40.10 \%, 27.40$ $\%$, and $22.99 \%$ to surface roughness, respectively. 
According to Table 6, the percentage contributions of the sphere material, sphere diameter, and sphere filling parameters on tool wear are $41.04 \%, 37.56 \%$, and $14.29 \%$, respectively. During prediction of tool vibration, cutting power, surface roughness, and tool wear, all exhibited low percentages of error, with $6.74 \%, 9.69 \%, 9.49 \%$, and $7.10 \%$, respectively. According to the results of the ANOVA study, the sphere material is the most important impact sphere particle damper parameter that influences cutting efficiency and damping capacity. MINITAB16 was used to carry out the ANOVA study. According to the ANOVA study, sphere material has a major impact on the damping efficiency, accompanied by sphere diameter and sphere filling.

Table 7. Levels of input parameters for getting optimum performance

\begin{tabular}{|c|c|c|c|c|}
\hline S.No & Objective & $\begin{array}{l}\text { Sphere } \\
\text { material }\end{array}$ & $\begin{array}{l}\text { Spher } \\
\text { e } \\
\text { diame } \\
\text { ter } \\
(\mathrm{mm})\end{array}$ & $\begin{array}{c}\text { Filling of } \\
\text { spheres }\end{array}$ \\
\hline 1 & $\begin{array}{c}\text { To } \\
\text { minimize } \\
\text { tool } \\
\text { vibration }\end{array}$ & $\begin{array}{l}\text { tungsten } \\
\text { carbide }\end{array}$ & 8 & $\begin{array}{l}\text { partially } \\
\text { packed }\end{array}$ \\
\hline 2 & $\begin{array}{c}\text { To } \\
\text { minimize } \\
\text { cutting } \\
\text { force }\end{array}$ & $\begin{array}{l}\text { tungsten } \\
\text { carbide }\end{array}$ & 8 & $\begin{array}{c}\text { partially } \\
\text { packed }\end{array}$ \\
\hline 3 & $\begin{array}{c}\text { To } \\
\text { minimize } \\
\text { surface } \\
\text { roughness }\end{array}$ & $\begin{array}{l}\text { tungsten } \\
\text { carbide }\end{array}$ & 8 & $\begin{array}{c}\text { partially } \\
\text { packed }\end{array}$ \\
\hline 4 & $\begin{array}{c}\text { To } \\
\text { minimize } \\
\text { tool wear }\end{array}$ & $\begin{array}{l}\text { tungsten } \\
\text { carbide }\end{array}$ & 8 & $\begin{array}{c}\text { partially } \\
\text { packed }\end{array}$ \\
\hline
\end{tabular}

Table 8. Evaluation of performance of tool holder

\begin{tabular}{|c|c|c|c|}
\hline Parameter & $\begin{array}{c}\text { Without } \\
\text { damper }\end{array}$ & $\begin{array}{c}\text { With } \\
\text { damper }\end{array}$ & Improvement \\
\hline $\begin{array}{c}\text { Vibration } \\
\text { amplitude of } \\
\text { tool (mm) }\end{array}$ & 3.28 & 0.2 & $93 \%$ \\
\hline $\begin{array}{c}\text { Tool Wear } \\
(\mathrm{mm})\end{array}$ & 0.21 & 0.015 & $92 \%$ \\
\hline $\begin{array}{c}\text { Surface } \\
\text { Roughness } \\
(\mu \mathrm{m})\end{array}$ & 4.08 & 0.18 & $95 \%$ \\
\hline $\begin{array}{c}\text { Cutting Force } \\
(\mathrm{N})\end{array}$ & 1250 & 170 & $86 \%$ \\
\hline
\end{tabular}

Table 7 summarizes the levels of input parameters for achieving minimal tool wear, tool vibration, cutting force, and surface roughness based on the experimental data and it was observed that the sphere material should be at level 3 (tungsten carbide), the sphere diameter should be at level $3(8 \mathrm{~mm})$, and the sphere filling should be at level 3 (partially packed) for reducing tool vibration and achieving better cutting efficiency. Confirmatory tests were carried out with the input parameters of tungsten carbide sphere material, sphere diameter of $8 \mathrm{~mm}$, and partly packed sphere fillings, and compared to a traditional boring tool. According to the confirmatory experimental findings in Table 8 , tool vibration was reduced by $93 \%$, cutting force was reduced by $86 \%$, surface finish was improved by $95 \%$, and tool wear was reduced by $92 \%$ for the tool equipped with a sphere particle impact damper.

Table 9. Confirmatory experiments for sphere particle impact boring tool and conventional tool

\begin{tabular}{|c|c|c|c|c|c|}
\hline $\begin{array}{l}\text { S.N } \\
0\end{array}$ & $\begin{array}{c}\text { Boring } \\
\text { Tool }\end{array}$ & $\begin{array}{l}\text { Vibra } \\
\text { tion } \\
\text { ampli } \\
\text { tude } \\
\text { of } \\
\text { tool } \\
(\mathrm{mm})\end{array}$ & $\begin{array}{l}\text { Tool } \\
\text { Wear } \\
(\mathrm{mm})\end{array}$ & $\begin{array}{l}\text { Cutti } \\
\text { ng } \\
\text { Force } \\
\text { (N) }\end{array}$ & $\begin{array}{l}\text { Surfa } \\
\text { ce } \\
\text { Roug } \\
\text { hness } \\
(\mu \mathrm{m})\end{array}$ \\
\hline 1 & $\begin{array}{l}\text { Conventional } \\
\text { boring tool }\end{array}$ & 3.28 & 0.21 & 1250 & 4.08 \\
\hline 2 & $\begin{array}{l}\text { Boring tool } \\
\text { with stainless } \\
\text { steel sphere }\end{array}$ & 2.77 & 0.17 & 842 & 3.87 \\
\hline 3 & $\begin{array}{l}\text { Boring tool } \\
\text { with } \\
\text { chromium } \\
\text { sphere }\end{array}$ & 2.32 & 0.13 & 767 & 3.46 \\
\hline 4 & $\begin{array}{l}\text { Boring tool } \\
\text { with tungsten } \\
\text { carbide sphere }\end{array}$ & 1.35 & 0.07 & 621 & 1.87 \\
\hline
\end{tabular}

\subsection{Effect of Sphere Material}

As compared to other passive dampers, the impact sphere particle damper has a greater influence on damping. The first is friction between spheres, which is influenced by the coefficient of friction, and the second is sphere impact force, which is influenced by the hardness and density of the sphere. From Table 36, ANOVA analysis indicated that sphere material is the most dominant parameter compared with sphere diameter and sphere fillings. In the present study sphere material such as stainless steel, chromium and tungsten carbide is considered. From Table 9, it can be found that tungsten carbide (density $19.25 \mathrm{~g} / \mathrm{cm}^{3}$ $\&$ hardness 9.5) provide reduced tool vibration, surface roughness, cutting force and tool wear when compared with stainless steel (density $7.5 \mathrm{~g} / \mathrm{cm}^{3} \&$ hardness 6.5) and chromium (density $7.14 \mathrm{~g} / \mathrm{cm}^{3}$ \& 
hardness 8.5). The damping property of the spheres is affected by the hardness and density of the sphere material.

The absorption of vibratory energy by losses that arise during the impact of granular spheres that travel freely inside the boundary of a cavity in a boring tool is known as sphere particle impact damping. If the sphere's hardness and density are high, the vibrating structure's energy is dissipated more efficiently by sphere contacts, and hence tool vibration is effectively minimized. When tool friction is reduced, the bouncing of the tool in and out of the workpiece is reduced, and irregularities on the surface are reduced, resulting in a smoother surface finish. Metal flow past the tool may be also as a result of reduced tool vibration, and tool pieces may not be separated. Furthermore, the enhanced surface finish caused by reduced tool vibration initiates only a slight crack initiation, resulting in longer tool life.

\subsection{Effect of Sphere Diameter}

Tiny spheres are mounted within the tool bar cavity to serve as an impact sphere particle damper. These spheres collide with the tool bar cavity as it vibrates, releasing vibration energy. To be able to turn holes any wider, spheres used as impact dampers must have a diameter that is slightly smaller than the cavity diameter. This is due to the dynamic of the balls' rotation, which creates damping due to the impact of the ball colliding with the cavity wall, allowing the friction energy of the bar to be dissipated. From Table 3-6, ANOVA analysis indicated that sphere diameter is the significant parameter subsequent to sphere material. In the present study sphere diameter such as $4 \mathrm{~mm}, 6 \mathrm{~mm}$ and $8 \mathrm{~mm}$ is considered. Figures 2, 3, 4, and 5 explicitly demonstrate that smaller spheres $(4 \mathrm{~mm}$ and $6 \mathrm{~mm}$ ) have less energy dissipation due to friction, resulting in increased tool vibration, cutting force, surface roughness, and tool wear. When the sphere's diameter is greater than half that of the hole, energy is dissipated further due to collision, resulting in less tool vibration, cutting force, surface roughness, and tool wear. As the mass of the spheres is larger and the distance between the spheres and the cavity wall is smaller, the damping effect of the spheres increases, resulting in an increase in the impact momentum transfer. The mass of the sphere increased by more than four times as the diameter was increased from 4 to $8 \mathrm{~mm}$. The findings suggest that the damping effect caused by the impact of the spheres on the cavity wall is greater as the spheres have more mass and the distance between the spheres and the cavity wall is smaller. When these spheres collide with the wall, a large amount of linear momentum is transferred from the tool bar holding the cavity to the spheres. The damping effect is determined by the change in linear momentum at the sphere's impact, which is determined by the sphere's material, density, and speed at the impact moments, and impact restitution coefficient. The larger the sphere diameter and the smaller the distance, the more the sphere impacts on the cavity wall are dampened. As a result, the impact sphere particle damper of $8 \mathrm{~mm}$ spheres produces a significant amount of damping.

\subsection{Effect of Sphere Fillings}

The sphere particle impact damper is made up of spheres in a cavity that dissipate energy by friction and impact. The number of spheres contained inside the cavity is also important. From Table $3-6$, ANOVA analysis indicated that sphere fillings is the least factor compared to sphere diameter and sphere material. In the present study sphere fillings such as tightly packed $(100 \%)$, loosely packed $(50 \%)$ and partially packed ( $80 \%)$ is considered. Figures $2,3,4$, and 5 shows that while spheres are closely packed, there is no energy dissipation from one sphere to another, while when they are loosely packed, and there is more energy dissipation from one sphere to another, resulting in increased vibration. While the spheres are partly compressed, however, the energy dissipation from one sphere to the next is precise, which improves the tribological properties. The findings reveal that the number of spheres within the boring tool has no impact on damping capabilities.

\section{CONCLUSIONS}

Experiments were carried out on a dull bar using an impact sphere particle damper to investigate the effects of sphere material, sphere diameter, and sphere fillings on tribological properties. The following conclusions were reached as a result of this study:

-There will be good interactions between the spheres and the cavity wall the larger the sphere diameter, the greater the damping.

-Higher density materials are preferred because they lead to greater damping. Hardness, on the other hand, was critical, and it is clear that hard sphere particles offered excellent damping and better tribology properties.

-As opposed to firmly packed and loosely packed spheres, partly packed sphere fillings have greater damping.

-It can be seen from the results of the experiments that spheres perform well as dampers. As a result, using an impact sphere particle in a dull instrument is a convenient and inexpensive way to reduce tool vibration and other tribological properties. 


\section{REFERENCES}

1. Diniz, Anselmo E., Wallyson Thomas Alves da Silva, Daniel Iwao Suyama, Robson Pederiva, and Marcos Vieira Albuquerque. (2019). Evaluating the use of a new type of impact damper for internal turning tool bar in deep holes. Int J Adv Manuf Technol. 101, 1375-1390.

2. Friend R D and Kinra V K. (2000). Particle impact damping. J Sound Vib 233, 93-118.

3. Khatake P and Nitnaware P T. (2013). Vibration mitigation using passive damper in machining. Inter. Jour. of Mod. Eng. Res. 3, 3649-3652.

4. Lawrance G, Sam Paul P, Ajay Vasanth X, Varadarajan A S and Benny Raj S. (2019). Suppression of tool vibration in boring process: A review. J. Inst. Eng. India Ser. C. 100, 1053-1069.

5. Lawrance G, Sam Paul P, Ajay Vasanth X, Varadarajan A S, and Daniel E. (2019). Influence of magnetorheological elastomer on tool vibration and cutting performance during boring of hardened AISI4340 steel. J Mech Sci Technol. 33, 1555-1561.

6. Lawrance G, Sam Paul P, Varadarajan A S, Praveen A P and Ajay Vasanth X, (2017). Attenuation of vibration in boring tool using spring controlled impact damper. J Interact Des Manuf. 11, 903-915.

7. Marhadi K S and Kinra V K. (2005). Particle impact damping: effect of mass ratio, material, and shape. J Sound Vib. 283, 433-448.

8. Panossian H V. (1992). Structural damping enhancement via non obstructive particle damping technique. J Vib Acoust. 114 101-105.

9. Ramesh K and Alwarsamy T. (2012). Investigation of modal analysis in the stability of boring tool using double impact dampers model development. Euro. Jour. of Sci. Res. 80, 182-190.

10. Sam Paul P, Varadarajan A S, and Lawrance G. (2015). Effect of material on damping characteristics of impact mass during hard turning. Emer. Mat. Res. 4, 81-88.

11. Sathishkumar B, Mohanasundaram K M and Senthilkumar M. (2012). Experimental studies on impact of particle damping on surface roughness of machined components in boring operation. Eur J Sci Res 71, 327-337.

12. Yang W H P and Tarng Y S. (1998). Design optimization of cutting parameters for turning operations based on the Taguchi method. Jour. of mater. Proc. Tech. 84, 122-129.
Received: July 17, 2021 / Accepted: December 15, 2021 / Paper available online: December 20, 2021 (C) International Journal of Modern Manufacturing Technologies 